\title{
Where are the Clawbacks?
}

\author{
Dane Christensen \\ University of Oregon \\ danec@uoregon.edu \\ Lance Gabrielsen * \\ University of Oregon \\ lgabriel@uoregon.edu \\ Kyle Peterson \\ University of Oregon \\ kylepete@uoregon.edu
}

\begin{abstract}
This study examines when and why firms claw back compensation from executives after a restatement. We find that despite the occurrence of thousands of restatements over 2004-2019, firms almost never use this important governance mechanism and claw back executive compensation. However, when it does happen it is more likely for restatements with alleged misconduct, more severe restatements, firms with multiple recent restatements, and firms that have a clawback policy. Moreover, firms seem to have responded to SEC enforcement of clawback laws by enforcing more clawbacks. We also investigate a potential substitute governance mechanism to clawbacks: the dismissal of responsible executives. We find some evidence that CEO or CFO dismissal is associated with a reduced likelihood of clawbacks. However, despite these findings, much of the puzzle of potentially under-utilized clawbacks remains.
\end{abstract}

\footnotetext{
We are grateful for helpful comments and suggestions from Nicole Johnson, and workshop participants at the University of Oregon. We also acknowledge financial support from the Lundquist College of Business at the University of Oregon.

- Corresponding author
} 


\section{1 - Introduction}

This study examines whether firms claw back compensation and under what circumstances this choice is and isn't made. Clawbacks are governance mechanisms which enable firms to reclaim ill-gotten compensation from executives when certain events, such as restatements, occur. In a time when executives are criticized for their allegedly excessive, legitimate compensation (Alsin, 2017; Francis and Fuhrmans, 2019), such mechanisms can be a valuable tool for firms. Unlike other governance mechanisms, which can only lessen the threat of future costs, clawbacks enable firms to recuperate lost resources spent on illegitimate compensation. Section 304 of the Sarbanes-Oxley Act of 2002 (SOX) was the first law to mandate clawbacks. Prior to this, very few firms had clawback policies that governed compensation. While SOX mandates clawbacks for the CEO and CFO of all firms under certain conditions, since the passing of the law, an increasing number of firms have chosen to voluntarily adopt their own clawback policies. These voluntary policies could cover a broader range of events than those covered by Section 304. Among S\&P 1500 firms, the percentage with policies grew from one percent in 2000 to over sixty percent in 2013 (Babenko, Bennett, Bizjak, and Coles, 2017). While the academic literature has investigated the adoption of these policies, there is no emperical evidence on instances when compensation is actually clawed back by firms with or without such policies.

Despite clawback policies gaining prominence among so many firms, we find that very few clawbacks are ever imposed upon executives. Over the period of 2004-2019, out of 6,736 restatements, 500 of which are alleged to be the result of misconduct, only 15 could be matched to a firm-initiated clawback of compensation. This phenomenon is visually captured in Figure 1 . The dearth of clawbacks is surprising given the prevalence of clawback policies. Commentary found in the business press suggests that potential deterrents to their use relate to the costs of the clawback litigation process exceeding the potential benefit or the difficulty of the clawback calculation 
(Lublin, 2010; Weiss, 2008). The former explanation may especially be the case if the firm receives a signal the executive will fight the clawback. Moreover, firms may be hesitant to clawback compensation for fear that it might be viewed negatively by the executive labor market and make it harder to attract high quality executives in the future. Alternatively, some academics postulate that the adoption of clawback policies may simply be window-dressing behavior and that firms have no intention of ever enforcing them (Denis, 2012; Pyzoha, 2015). Still, this phenomenon is puzzling because even if the benefits of a clawback are immaterial to the firm, the penalty imposed on the executives may be material. And even if the monetary penalty is immaterial to executives, the clawback represents a negative public signal the executives would probably prefer to avoid. In either case, clawbacks could serve in establishing strong governance within the firm, which was likely the intended purpose of SOX Section 304. Therefore, it appears clawbacks may be a potentially underutilized governance mechanism.

\section{[INSERT FIGURE 1 HERE]}

We begin our investigation by examining the determinants of firm-initiated clawbacks. Given that securities laws (i.e., SOX) mandate clawbacks for restatements resulting from misconduct, we focus on characteristics of restatements that speak directly to their likelihood of being caused by misconduct (e.g., if the restatement is associated with fraud or an SEC investigation). We also collect data on characteristics of the severity of restatements that indirectly indicate the likelihood of the presence of misconduct (e.g., the length of the restatement or overstatements). However, as mentioned above, not all firms' policies require misconduct for a clawback to occur. Some firms define a broader set of restatements that trigger clawbacks. Therefore, by including all restatements in our analyses we can speak to clawbacks that should have occurred under both the law and the firms' own policies. Using a sample of restatements from 
2004-2019, with clawbacks identified from proxy statements (i.e., DEF 14A), as well as 10K and 8K filings, we regress clawbacks on the incidence of alleged misconduct, indicators of the severity and complexity of the restatement, and the presence of a clawback policy at the offending firm. We predict and find a positive relation between clawbacks and each of these potential determinants. These results suggest that the severity of a restatement does play a role in a firm's decision to claw back compensation from its executives. Nevertheless, these factors only explain a small fraction of the variation in clawbacks. Moreover, while there is a positive relation between clawback policies and actual clawbacks, the majority of firms with clawback policies and misconduct restatements did not actually claw back compensation, suggesting many firms' policies are in fact window dressing.

Next, we examine whether SEC enforcement of SOX 304 influenced the likelihood of firms clawing back compensation. Prior research has found that as information about SEC enforcement increases, firms are more likely to self-regulate (Kedia \& Rajgopal, 2011). When SOX was passed in 2002, firms received information about the possibility of SEC enforcement of clawbacks. However, when Section 304 was first solely enforced in 2009, firms received additional—and arguably more important—information about SEC enforcement (Mahoney, 2009). We predict that more firms claw back compensation from their executives after 2009. In fact, before 2009, firm-initiated clawbacks were nearly non-existent. And although clawbacks post-2009 are still rare, these results suggest that SEC enforcement of Section 304 may have had at least some effect on firms' self-regulating behavior.

Next, we investigate one potential substitute to clawbacks: the dismissal of responsible executives. Prior research has shown that reputational costs to fired managers are significant (Desai, Hogan, and Wilkins, 2006; Karpoff, Lee, and Martin, 2008), thus serving as an effective 
alternative deterrent of unwanted behavior. As such, firms could use dismissals of executives as a substitute governance mechanism to clawbacks if the costs and benefits suggest it would be preferable to clawing back compensation. However, these two governance mechanisms could be complements. Firms may feel more inclined to also claw back compensation if the executive's behavior was egregious enough to be fired in the first place. To investigate this relation, we rerun the base model mentioned above but include a variable indicating whether the firm dismissed its $\mathrm{CEO}$ or $\mathrm{CFO}$ in the six months prior and subsequent to a restatement. We find that dismissal of a CEO or CFO is associated with a decreased likelihood of clawbacks. Moreover, the likelihood of a clawback appears to be even lower when executives are dismissed for misconduct-related restatements. These actions are consistent with clawbacks and dismissals being substitutes.

In supplemental analyses, we rerun the previous tests on a subsample of restatements with alleged misconduct to assuage concerns that not all restatement firms in the full sample have experienced a clear signal that a clawback is necessary. In these tests, we find qualitatively similar results. We also investigate the possibility of "silent clawbacks," that is, firms which claw back compensation in response to restatements, but do not disclose the clawback explicitly. We find that total compensation of CEOs and CFOs does not appear to be affected by the occurrence of a restatement with alleged misconduct, suggesting that silent clawbacks are not prevalent. Lastly, we repeat the initial determinants analysis using SEC-enforced clawbacks. Similar to firm initiated clawbacks, SEC-enforced clawbacks are also quite rare, as we are only able to identify 24 such clawbacks that are related to restatements. Despite none of these instances of clawbacks overlapping with the collection of firm-initiated clawbacks, we find qualitatively similar results on the determinants of SEC-enforced clawbacks. These results only contribute to the puzzle of underutilized clawbacks: both firms and the SEC appear to be weakly reacting to the same 
stimuli — but neither seems overly committed to the widespread application of this governance mechanism.

This study contributes to the literature in two ways. First, we investigate an unstudied aspect of the literature: a firms' choice to claw back compensation from executives. Prior studies have solely focused on the determinants and effects of the choice to voluntarily adopt clawback policies. These studies find that the adoption of policies is quite prevalent (Babenko et al., 2017). In contrast, we find that firms almost never claw back compensation from executives. These findings raise questions regarding whether more broadly defined clawback policies, such as those championed by the Dodd-Frank Act of 2010 (which have yet to be implemented), would have their intended effect on firms. We also offer some insight into some of the restatement characteristics that appear to trigger clawbacks (e.g., restatements with alleged misconduct, the size of the restatement, and restatements after 2009). However, much of the puzzle of potentially underutilized clawbacks remains.

Second, this study speaks to the findings of prior literature concerning clawback policies. Our findings appear to suggest that the adoption of these policies is primarily window-dressing behavior. Despite the widespread adoption of clawback policies, it is rare for firms to impose them on their executives. Even SEC enforcement of Section 304 seems to have only had a modest effect on firms' behavior, as in only seven percent of restatements with alleged misconduct did firms claw back compensation from executives since 2009. Moreover, the implications of such window dressing may affect the inferences of research concerning the adoption of clawback policies. For example, previous studies have found that policy adoption is associated with an improved financial reporting environment (Chan, Chen, Chen, \& Yu, 2012; Dehaan, Hodge, \& Shevlin, 2013). 
However, if the trend of infrequent clawbacks continues, these positive effects may dissipate over time as managers learn that the threatened penalties of clawback policies are superficial.

\section{2 - Hypothesis Development}

\section{1 - Institutional Background}

On July $30^{\text {th }}$, 2002, President George Bush signed the Sarbanes-Oxley Act into law. In Section 304 of this Act, Congress included statutes that require executives to reimburse the firm for ill-gotten compensation under certain conditions. Specifically, the section states that the CEO and $\mathrm{CFO}$ of firms that have had "restatement[s] due to a material noncompliance, as the result of misconduct," are to disgorge related bonuses or incentive-based compensation (U.S. Congress, 2002). In cases of non-compliance, the Securities and Exchange Commission (SEC) is charged with enforcing this law. Despite the occurrence of hundreds of intervening - and potentially deserving restatements-it was not until nearly seven years later, on July $22^{\text {nd }}, 2009$, that the SEC issued an enforcement action solely under this clawback policy of SOX (SEC, 2009). In the enforcement action, the commission sought the return of $\$ 4$ million in bonuses and stock sale profits from a former CEO of CSK Auto Corp, a firm accused of committing accounting fraud. ${ }^{1}$

Lawmakers have made attempts to strengthen the clawback policy of Section 304. In Section 954 of the Dodd-Frank Act of 2010 (DFA) the SEC is required to adopt rules that prohibit the listing of any firm that does not have a clawback policy for restatements due to material noncompliance with any securities law (and not just those cases that result from misconduct) (U.S.

\footnotetext{
${ }^{1}$ On a few occasions, the SEC enforced Section 304 prior to 2009. The first reference we found in SEC enforcements to SOX Section 304 was released on May 31, 2007. However, the enforcement in 2009 is the SEC's first stand-alone enforcement of Section 304 and has been the focus of prior literature. Furthermore, the SEC placed particular emphasis on this clawback case. See https://www.sec.gov/news/press/2009/2009-167.htm for more information.
} 
Congress, 2010). ${ }^{2}$ On June $30^{\text {th }}$, 2015, the SEC called for comments on a proposed rule (SEC, 2015). No updates on the rule's progress have since been issued.

Since the passing of Section 304, many firms have adopted their own clawback policies (Babenko et al., 2017). While these policies typically have much in common with Section 304, they can differ with respect to the scope of restatements that are subject to clawbacks. For example, some policies do not require the standard of misconduct to apply to a restatement for compensation to be subject to the clawback policy. Our research question, and the bulk of this study investigates these firm-initiated clawbacks. In supplemental analyses, we consider SEC-enforced clawbacks.

\section{2 - Literature Review}

The academic literature investigating voluntary clawback policies has found that firm size, extraordinary mergers-and-acquisition bonuses, goodwill impairments, restatements from irregularities, and the scope of corporate malfeasance, executives' compensation and governance are all positively associated with their adoption (Babenko et al., 2017; Brown, Davis-Friday, and Guler, 2012). Moreover, after the adoption of clawback policies, the incidence of restatements appears to decline (Chan et al., 2012) and investors tend to view these policies as increasing accounting quality and lowering audit risk (Chan et al., 2012; Dehaan et al., 2013). Furthermore, non-GAAP earnings disclosure frequency appears to increase and non-GAAP exclusion quality tends to decrease (Kyung, Lee, \& Marquardt, 2018). Finally, shareholders of adopting firms tend to experience a reduction in stock volatility (Babenko et al., 2017) and positive stock returns (Iskandar-Datta and Jia, 2013), highlighting investors' approval of clawback policies.

\footnotetext{
${ }^{2}$ Additionally, the Emergency Stabilization Act of 2008 allowed for clawbacks of bonuses and incentive-based compensation paid to an executive or the next 20 highest-paid employees. This law broadened the definition of what triggers are subject to clawback to all cases where financial results are found to be inaccurate (U.S. Congress, 2008). However, this law only applies to firms that received funds from the Troubled Asset Relief Program (TARP).
} 
However, some of the benefits of clawback policies have been questioned, suggesting that at least part of the reduction in restatements found by Chan et al., (2012) may be attributable to managers' finding alternative ways to manage earnings, rather than increasing financial reporting quality (Denis, 2012; Pyzoha, 2015). For example, firms with clawback policies appear to substitute accruals earnings management with real earnings management, especially when strong incentives to meet short-term targets are present (Chan, Chen, Chen, \& Yu, 2015).

\section{3 - Hypotheses}

Both Section 304 of SOX and voluntary clawback policies cite the occurrence of a restatement as their triggering event. However, in the case of SOX, the triggering event is narrow, as it requires that restatements must be the result of misconduct. In restatements where fraud is alleged to have taken place, this threshold is likely met: any fraudulent behavior should constitute misconduct. Restatements associated with SEC investigations (not necessarily associated with violations of Section 304) are also prime suspects to be considered, though the connection to misconduct is not certain. Given the Commission's limited resources, it is reasonable to assume it only chooses to pursue cases where firms are likely to have violated accounting standards or securities law. While not all these firms will have perpetrated behavior consistent with misconduct, misconduct is more likely to be found in this subset of restatements. Therefore, it is reasonable to suspect a greater likelihood of firm-initiated clawbacks if this higher threshold is met. Therefore, we hypothesize the following:

H1a: Firm-initiated clawbacks are more likely when firms experience restatements with alleged misconduct (i.e., those associated with fraud or an SEC investigation).

Other characteristics of restatements may be indicative of their potential to be construed as the result of misconduct. The length of a restatement period and the magnitude of the overstatement 
are indicators of their severity and therefore the lengths executives could have to take to conceal the discrepancy. Such behavior could constitute misconduct. Another indicator of misconduct is the number of other recent restatements a firm has had. If a firm's reporting environment allows for multiple restatements, it is reasonable to assume that same environment may be one where misconduct is more likely to be found. Therefore, it is plausible that in cases of longer restatements, overstatements, or multiple recent restatements, a clawback would be more likely to occur. Moreover, the more severe the restatement, the greater the potential cash flow the firm is likely to receive if it claws back executive compensation. Thus, we also hypothesize:

H1b: Firm-initiated clawbacks are increasing in the severity of the restatement.

Firms that have previously adopted clawback policies have committed themselves to a course of action their stakeholders should hold them to. On average, it is reasonable to expect that because a firm made this prior commitment to claw back compensation, it will be more likely to do so, if given an appropriate opportunity. Therefore, we hypothesize:

H1c: Firm-initiated clawbacks are more likely if the firm has previously adopted a clawback policy.

As information about SEC enforcement increases, firms are more likely to self-regulate (Kedia \& Rajgopal, 2011). When SOX was passed, firms received information about the possibility of SEC enforcement regarding clawbacks. However, when Section 304 was first solely enforced in 2009, firms received additional information about the SEC's commitment to the enforcement of clawbacks. Given the high costs, both reputational and otherwise, associated with SEC enforcement actions, it is reasonable to assume that firms would try to avoid such a proceeding. Firms would then prefer to claw back their own executives' compensation rather than having the SEC step in and claw it back for them. Therefore, we also hypothesize: 
H2: Firm-initiated clawbacks are more likely to occur in cases of restatements after the first standalone SEC enforcement of SOX Section 304.

Although clawbacks represent a governance mechanism firms may employ in response to a restatement, other governance mechanisms also exist which firms may employ. One alternative to clawbacks, the dismissal of at-fault executives, may be more attractive to firms for several reasons. Perhaps the most important reason is that in dismissing an executive, there is no protracted legal battle over which compensation was ill-gotten and which was legitimate. There is a clean break and the firm can start anew, without excessive legal costs. This suggests that compensation clawbacks and dismissals could be substitute governance mechanisms. However, these two mechanisms could also be complements. Firms may feel more inclined to claw back compensation if the executive's behavior was egregious enough to be dismissed. Additionally, in such cases, the compensation recovered from the clawback may be greater, potentially increasing the likelihood of a clawback. Therefore, and lastly, we hypothesize, stated in null form:

\section{H3: Firm-initiated clawbacks are not associated with CEO or CFO dismissal.}

\section{3 - Research Design}

\section{1 - Sample Construction}

For our main analyses, we collect all restatements filed during the years 2004-2019 from the Audit Analytics Non-Reliance Restatements database. This database includes information concerning whether the restatement was the result of fraud, an SEC investigation, or an error, the beginning and end of the restatement period, the net change in net income as a result of the restatement, and historical financial statement variables, including sales, total assets, and market value. For each of these restatements, we obtain data regarding clawback policy adoption, clawbacks, and executive turnover. 
Following prior literature, we obtained data on clawback policy adoptions by searching for clawback-policy related language in all firms' Proxy Statement (DEF 14A) filings. ${ }^{3}$ The complete list of search terms used is as follows: clawback; recapture policy; compensation recovery, pay recovery, award recovery, or bonus recovery, compensation recoupment, pay recoupment, award recoupment, or bonus recoupment. Additionally, we searched for derivatives (e.g., recoup, clawed back) and reversals of order (e.g., recovery of compensation) of applicable terms. We then removed any instances where negation language is used (e.g., "we do not have a clawback policy") or other common, but not relevant ways our search terms might be used (e.g., "retail clawback" or "FDIC clawback"). From this set of observations, we recorded the first date (i.e., the date the proxy meeting was to take place) clawback related language is used in a firm's proxy statement and define this as that firm's clawback adoption date.

We obtained data on clawbacks by searching firms' Proxy Statement filings for the same clawback-related terms mentioned above, but expand our search to include $10 \mathrm{~K}$, and $8 \mathrm{~K}$ filings to ensure firms are not disclosing clawbacks via different means. ${ }^{4}$ As there exists no prior literature as to how soon after a restatement the typical firm claws back compensation, we searched over all years available on EDGAR and not just those associated with firms' restatements. In these filings, for every paragraph that had some mention to a clawback based on the above search terms, we searched for language that suggests the firm imposed a clawback (e.g., references to a recent

\footnotetext{
${ }^{3}$ Prior studies have used third-party datasets on clawback policies that draw on DEF 14A filings (e.g., such as those owned by Incentive Lab and MSCI). These datasets were not employed in this study given their limited time coverage.

${ }^{4}$ While all the clawback observations were found in DEF 14A filings, several clawbacks were mentioned in multiple filings. This includes one clawback that was mentioned in both DEF 14A and 8K filings and four that were mentioned both DEF 14A and 10K filings.
} 
restatement/misstatement or discussion of dollar amounts paid) and then manually searched through these filings to determine the presence of a clawback. ${ }^{5}$

We obtained data on executive dismissal by collecting all instances of CEO or CFO turnover in Audit Analytics' Director and Officer Changes database. We only include instances of turnover in these two positions to align with the scope of SOX Section 304. These data include the date of departure and indicators of why an executive left the firm (e.g., if they were dismissed or resigned).

We link clawbacks to restatements if they occurred within twenty-four months subsequent to the restatement date. A twenty-four-month window is chosen because the clear majority of clawbacks found occur within this time span and is in line with anecdotes found in Proxy Statements in which clawbacks have occurred. This matching process resulted in a few cases where multiple restatements were linked to a single instance of clawback. These instances were allowed in the sample given it was not clear which restatement could be attributed to the clawback.

For executive turnover, we require the turnover date to be within six months prior or subsequent to the restatement date. This range is chosen because prior literature has found that in such a twelve-month window surrounding a restatement, the majority of turnover has already occurred and is most likely to be associated with the restatement (Hennes, Leone, \& Miller, 2008). ${ }^{6}$ From this merged dataset, we create our variables of interest. Table 1 summarizes the sample construction process.

\section{2 - Models and Variable Definitions}

\footnotetext{
${ }^{5}$ Firms may use similar language concerning restatements and dollar amounts when describing their clawback policies, resulting in false positives. For example, of the initial 19,369 Proxy Statement filings with clawback-policy related language, 11,892 made references to restatements and 961 that included a dollar sign. Therefore, a manual search was needed to accurately distinguish which constituted actual clawbacks.

${ }^{6}$ Other windows, including a 24-month period subsequent to a restatement and the 30-month period discussed in Hennes et al., (2008), result in comparable findings.
} 
To test Hypotheses 1a-1c, we estimate the following equation using a linear probability model:

Firm Clawed $=\beta_{0}+\beta_{1}$ Misconduct $+\beta_{2}$ Restatement Length $+\beta_{3}$ Overstatement + $\beta_{4}$ Multiple Restatements $+\beta_{5}$ Clawback Policy $+\beta_{6}$ Log Total Assets $+\varepsilon$

where Firm Clawed is an indicator set equal to one if, in the 24 months following a restatement, a firm imposes a compensation clawback on its CEO or CFO. The first variable of interest, Misconduct, is an indicator set equal to one if, according to Audit Analytics, the restatement is associated with fraud or an SEC investigation. As mentioned above, these two flags are likely to indicate the presence of misconduct within a firm. Restatement Length is a continuous independent variable set equal to the difference in months between the beginning and end dates of a given restatement period. This variable indirectly measures the potential complexity or magnitude of a restatement. Overstatement is a dummy variable set equal to one if a firm's net overstatement is greater than zero. ${ }^{7}$ This variable proxies for the severity of a restatement. Multiple Restatements is an indicator set equal to one if, in the five-year period preceding a restatement, the firm issued at least one other restatement. This variable attempts to measure the quality of the reporting environment of a firm. For example, having multiple recent restatements could be an indicator of the presence of misconduct at the firm. The final variable of interest, Clawback Policy, is also an indicator which is set equal to one if a firm's clawback-policy-adoption date (if a policy is present at all) is before a given restatement. This variable captures a firm's prior commitment to claw back compensation. We also control for firm size, Log Total Assets, to help remove any confounding

\footnotetext{
7 The net overstatement corresponds to the Audit Analytics Variable "Cumulative Change in Net Income." For ease of interpretation, we multiply this measure by negative one. Therefore, an increase in Net Overstatement indicates a more severe restatement. In untabulated analyses, we implement an alternate measure, namely the tercile of Net Overstatement and find qualitatively similar results. Other numbers of groups were considered $(4,5$, and 10), but in each case, at least one bucket within the groups had identical bin edges given the highly skewed distribution of the "Cumulative Change in Net Income" (e.g., [0, 0], [0, 0]).
} 
effects that may be present for either small or large firms. This variable is the natural logarithm of historical total assets divided by one million, as obtained from the Audit Analytics Non-Reliance Restatements database.

To test the predictions in Hypothesis $2 \mathrm{a}$ and $2 \mathrm{~b}$, we make the following adjustments to Equation 1:

$$
\begin{aligned}
& \text { Firm Clawed }=\beta_{0}+\beta_{1} \text { Misconduct }+\beta_{2} \text { Post } 2009+\beta_{3} \text { Post } 2009 * \text { Misconduct }+ \\
& \beta_{4} \text { Restatement Length }+\beta_{5} \text { Overstatement }+\beta_{5} \text { Multiple Restatements }+\beta_{6} \text { Clawback Policy } \\
& +\beta_{7} \text { Log Total Assets }+\varepsilon
\end{aligned}
$$

where Post 2009 is an indicator set equal to one if the restatement occurred after July $22^{\text {nd }}, 2009$, the date of the first standalone SEC enforcement of Section 304 of SOX. ${ }^{8}$ This variable captures the potential effect enforcement of accounting standards and securities laws may have on firms' self-regulating behavior.

To test Hypothesis 3, we make the following adjustments to Equation 1:

$$
\begin{aligned}
& \text { Firm Clawed }=\beta_{0}+\beta_{1} \text { Misconduct }+\beta_{2} \text { Dismissal }+\beta_{3} \text { Dismissal } * \text { Misconduct }+ \\
& \beta_{4} \text { Restatement Length }+\beta_{5} \text { Overstatement }+\beta_{5} \text { Multiple Restatements }+\beta_{6} \text { Clawback Policy } \\
& +\beta_{7} \log \text { Total Assets }+\varepsilon
\end{aligned}
$$

where Dismissal is an indicator variable set to equal one if, in the six months prior or subsequent to a restatement, the firm experiences CEO or CFO turnover due to dismissal as defined by Audit Analytics, and zero otherwise. Following Shen \& Cannella (2002), we exclude cases where turnover was the consequence of the CEO or CFO's death or health issues, the CEO or CFO's

\footnotetext{
${ }^{8}$ An alternate post dummy, which was set equal to 1 if a restatement occurred after May 31, 2007 (the date of the first SEC litigation release which mentioned SOX, Section 304), was also implemented and resulted in qualitatively similar results. See www.sec.gov/litigation/litreleases/2007/lr20136.htm.
} 
acceptance of a similar position at another firm, a merger or acquisition, or the ending of an interim position.

All continuous variables are winsorized at the first and ninety-ninth percentiles to mitigate the effect of outliers. All regressions, unless specified otherwise, include year fixed effects and have standard errors clustered by firm. ${ }^{9}$ Moreover, we also calculated Variance Inflation Factors (VIFs) for all models and these did not indicate any issues with multicollinearity. Appendix A summarizes all variable definitions.

\section{4 - Results}

\section{1 - Univariate Results}

Appendices B and C present details concerning each observed clawback and excerpts from three firms' Proxy Statements, respectively. In total, eleven clawbacks were matched with at least one restatement in the sample, resulting in 15 total restatements that are linked to a clawback. ${ }^{10}$ In each of these cases, clawbacks were imposed upon a mean (median) of 3.73 (3) executives and resulted in the mean (median) return of $\$ 543,242(\$ 239,349)$ of primarily incentive-based compensation to the firm. This return represents a mean (median) return of 6.46 percent $(6.75$ percent) of relevant total compensation. Affected executives in most cases included either the CEO or CFO and, in several cases, all named executive officers (NEOs).

Table 2 presents the descriptive statistics for the sample. In Panel A, the results for the full sample are presented. As discussed above, clawbacks are rare occurrences. This is corroborated by the mean of the variable Firm Clawed, which indicates that only 0.2 percent of restatements are ever associated with a clawback. This is contrasted with the mean of Misconduct, which suggests

\footnotetext{
${ }^{9}$ A single-variable time trend was tried in place of year fixed effects. Qualitatively similar results were found. ${ }^{10}$ Fourteen clawbacks, in total, were found by searching available filings on EDGAR. Three were lost due to data requirements.
} 
that 7.4 percent of restatements are alleged to have misconduct. Therefore, even in cases where it appears the threshold of misconduct has likely been met, compensation is clawed back only 2.7 percent of the time. In addition, in the entire sample, 21.3 percent of restatements were issued by firms that had previously indicated that they had clawback policies. This again raises the question as to why more firms are not clawing back compensation, especially when many have already committed to do so and SOX requires it. Moreover, this suggests that clawback policies may be little more than window dressing. In contrast, the CEO or CFO was dismissed in 0.09 percent of restatements. Though not indicative of a substitution effect, the relatively higher frequency of dismissal may suggest that firms are choosing this mechanism instead of clawbacks. Additionally, about half of the restatements in the sample (51.7 percent) occurred after July $22^{\text {nd }}, 2009$, suggesting that the sample is not more prevalent in one period or the other. Lastly, the mean (median) size of firms for the sample is 7.69 (7.62), suggesting that size is not highly skewed. When comparing to the mean (median) size for all Compustat firms over the same period, 2.48 (2.61), the relatively large size of the firms in the sample is apparent.

In Table 2, Panel B, descriptive statistics are presented for partitions on the dependent variable, Firm Clawed. Comparison between these partitions offers the following important insights. First, alleged misconduct is present in over 40 percent of restatements that had clawbacks verses 7.4 percent in restatements that did not have clawbacks. The statistically significant $(p<$ 0.01) higher frequency of misstatements with alleged misconduct among enforcing firms is consistent with Hypothesis 1a. Second, all three proxies for the severity or complexity of a restatement are of greater magnitude or more prevalent when clawbacks occurred, though only two are statistically different from each other. Although Restatement Length is on average, eight months longer for firms with clawbacks, this difference is not statistically significant at 
conventional levels. However, there are more than twice the proportion of overstatements in restatements with clawbacks than in non-clawback restatements (difference $=0.437, p<0.01$ ) and Multiple Restatements is present in 25.5 percent more of clawback restatements than those without $(p<0.1)$. These indicators suggest that more severe restatements are more likely to be associated with a clawback and are consistent with our predictions in Hypothesis 1b. Third, in cases where clawbacks occur, firms are much more likely to have adopted a clawback policy $(p<0.01)$. This suggests that the prior commitment to claw back compensation may increase the likelihood of a clawback and is consistent with our prediction in Hypothesis 1c. Fourth, 86.7 percent of clawbacks occurred after the first enforcement of Section 304 in 2009 versus 51.6 percent in the no-clawback subset (difference $=35.1$ percent, $p<0.01$ ). This comparison suggests that SEC enforcement may have increased firms' self-regulating behavior (i.e., clawing back compensation) and is consistent with our prediction in Hypothesis 2. Fifth, restatements without clawbacks, about three percent are issued by firms that experience turnover due to dismissal (Dismissal) of a CEO or CFO in the six months prior or subsequent to a restatement. In restatements with clawbacks, none experience such dismissal (difference $=-0.09$ percent, $p<0.01$ ). These comparisons may suggest that clawbacks and dismissals are substitutes, speaking to the relation mentioned in Hypothesis 3. Lastly, comparison of firm size between the partitions suggests that on average, clawbacks are more common for larger firms (difference $=1.323, p<0.01$ ). This result highlights the importance of controlling for firm size in the following regressions. Table 3 presents both Pearson (lower diagonal) and Spearman (upper diagonal) correlations. Inferences drawn from these correlations are qualitatively similar to those drawn from the descriptive statistics.

4.2 - Determinants of Clawbacks (Hla-1c) 
Table 4, Column (1) presents the multivariate results of Equation 1 using a linear probability model. These results speak to the predictions made in Hypotheses 1a-1c. Overall, the model is fairly poor at explaining variation in the data (Adjusted $\mathrm{R}^{2}=0.008$ ). However, this is not surprising, given that few restatements have a clawback associated with them. Consistent with Hypothesis 1a, the coefficient on Misconduct is positive and statistically significant $(p<0.05)$. This suggests that, all else equal, when a restatement is alleged to be the result of misconduct, there is a one percent higher likelihood of a clawback. In comparison to the coefficients of the other variables of interest, the economic magnitude of Misconduct is quite large, especially given the rare incidence of clawbacks. The multivariate results are also mostly consistent with Hypothesis 1b. While the coefficient on Restatement Length is positive, it is not statistically significant at conventional levels. However, both the coefficients on Overstatement and Multiple Restatements are positive and at least marginally statistically significant $(p<0.01$ and 0.10 , respectively). These results suggest that the direct severity of the restatement and the strength of the firm's financialreporting environment play a relatively larger role in a firm's decision to claw back compensation than the complexity of the restatement (as proxied by Restatement Length). Consistent with Hypothesis 1c, the coefficient on Clawback Policy is positive and marginally significant $(p<0.10)$. These results indicate that, all else equal, firms that issue a restatement and have previously adopted a clawback policy have a 0.53 percent higher likelihood of imposing a clawback.

\section{3 - The Effect of SEC Enforcement (H2)}

Table 4, Columns (2) to (4) presents the results of Equation 2, which tests the predictions made in Hypothesis 2 that firm-initiated clawbacks will be more likely to occur following the first SEC enforcement of SOX Section 304. In Column (2), the coefficient on Post 2009 is positive and marginally significant $(p<0.10)$. This suggests that overall, clawbacks are 0.2 percent more likely 
after the SEC first enforced Section 304 of SOX. All other coefficients have similar interpretations to those in Column (1). In Column (3), we find that the coefficient on the interaction between Misconduct and Post 2009 is positive and statistically significant $(p<0.05)$. This suggests that after the first enforcement of Section 304 and in cases of restatements with alleged misconduct, clawbacks have a 2.3 percent greater probability $(0.0024+0.0201=.0225$, $\mathrm{p}$-value $<0.05)$, which is of greater magnitude (and statistically significant) when compared with the small and statistically insignificant coefficient before 2009. Column (4) adds year fixed effects to the model. As such, the standalone variable Post 2009 is dropped, given its perfect collinearity with the fixed effects. The results of this regression are qualitatively similar to the results given in Column (3), although the coefficient on the interaction between Misconduct and Post 2009 decreases in magnitude from 2.01 to 1.94 percent. The adjusted R-squared for the models testing Hypothesis 2 continue to be quite low $(0.009,0.01$, and 0.011 , respectively). Again, this can be partially attributed to the very few clawbacks in the sample. Together, these results are consistent with Hypothesis 2.

\section{4 - Dismissal, a Potential Substitute to Clawbacks (H3)}

Figure 2 presents yearly counts of CEO or CFO turnover due to dismissal, restatements with alleged misconduct, and clawbacks. As in Figure 1, the line representing clawbacks is nearly indistinguishable from the $\mathrm{x}$-axis. However, in this figure, the line representing restatements with alleged misconduct is closely tracked by dismissals in most years. This evidence is consistent with firms using dismissals in response to alleged misconduct as opposed to compensation clawbacks.

Table 4, Columns (5) to (6) presents the results of Equation 3, which tests the predictions made in Hypothesis 3. In Column (5), Dismissal is added to Equation 1. In this specification, the coefficient on Dismissal is negative and statistically significant $(p<0.01)$. In Column (6), 
Dismissal is interacted with Misconduct. Even in the presence of the interaction, the coefficient on Dismissal remains negative and statistically significant $(p<0.01)$. All other variables have similar interpretations to their counterparts in past regressions. These results suggest that there exists a negative relation between Misconduct and Dismissal, and that the two may be substitutes. Moreover, the combined effect of the Misconduct-Dismissal interaction is statistically indistinguishable from zero at conventional levels $(0.0103+-0.0097=0.0006)$, suggesting that Dismissal counteracts the higher likelihood of clawbacks that a firm might experience by having a restatement with alleged misconduct. Together, these results indicate that dismissals may serve as a substitute governance mechanism to clawbacks. Therefore, these findings reject the null Hypothesis 3 and indicate clawbacks are negatively associated with CEO or CFO dismissal.

\section{5 - Supplemental Analyses}

\subsection{1 - Tests on Misconduct Sample}

Table 5, Panel A presents the summary statistics for only restatements with alleged misconduct. We re-estimate our tests with this more restricted sample given the possibility that in the full sample, not all firms have experienced a clear clawback trigger. For example, some may have issued restatements because of accounting misapplications or clerical errors. In this subsample, all firms have issued similarly egregious restatements. Of note is the relatively higher percentage of clawbacks (1.2 percent) when compared to the overall sample ( 0.2 percent). While this indicates that more firms impose clawbacks in cases where the threshold of misconduct is likely met, it still only represents a small proportion. Additionally, 14.6 percent of restatements with alleged misconduct were issued by a firm that had previously issued a clawback policy, compared to 22.3 percent in the entire sample. This may suggest that the presence of a clawback policy at a firm is associated with less egregious restatements and therefore, higher quality 
financial reporting. This is consistent with the tone of findings in prior literature. Lastly, Dismissal is more common in the misconduct subsample than in any other sample examined thus far (1.8 percent of restatements). These results may suggest that dismissal may be a more attractive governance mechanism for firms issuing restatements with alleged misconduct and is thus implemented instead of clawbacks.

Table 5, Panel B presents the results of some of the previously mentioned regressions, but only for restatements with alleged misconduct. All are estimated using linear probability models. Column (1) presents results of the equation testing Hypothesis $1 \mathrm{~b}$ and 1c. While similar coefficients are obtained for Restatement Length, Overstatement, and Multiple Restatements, the coefficient on Clawback Policy is no longer statistically significant at conventional levels. This is consistent with clawback policies being window dressing because while the severity of a restatement appears to affect firms' likelihood of imposing clawbacks, issuing firms' prior commitment to clawbacks does not. Column (2) presents the regression results for the equation testing Hypothesis 2. While all other variables have similar interpretations as in Column (1), the coefficient on Post 2009 is not statistically significant in the partitions. This suggests that for restatements with alleged misconduct, the degree of SEC enforcement of securities laws does not seem to matter. In Column (3), the results for the equations testing Hypothesis 3 are presented. Despite a higher frequency of dismissal in this subsample, the coefficient on Dismissed is not statistically significant from zero. While not indicative of a substitution effect, these findings are consistent with the notion that in cases of more egregious restatements (and therefore, potentially greater payoffs), firms are no less likely to clawback compensation even if they choose to dismiss responsible executives.

\subsection{2 - Tests on "Silent" Clawbacks}


An alternative explanation for the dearth of clawbacks is that firms might be taking back compensation from executives but not disclosing that they are doing so. To test this possibility, we estimate the following equation using ordinary least squares:

$$
\begin{aligned}
& \text { Executive Incentive } \text { Comp }_{t}=\beta_{0}+\beta_{1} * \text { Restatement }_{t}+\beta_{2} * \text { Misconduct Restatement }_{t}+ \\
& \beta_{3} * \text { Executive Turnover } t+\beta_{4} * \text { Log Total Assets } t+\beta_{5} * R O A_{t}+\beta_{6} * \text { Sales Growth }_{t}+ \\
& \beta_{7} * \text { Adjusted Return } V W_{t}+\beta_{8} * \text { Return Volatility } t+\varepsilon
\end{aligned}
$$

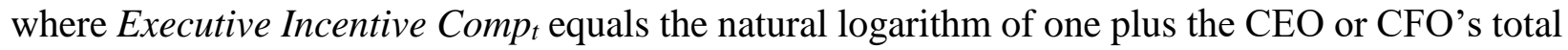
incentive compensation (the sum of ExecuComp variables bonus, noneq_incent, option_awards_fv, and stock_awards_fv). ${ }^{11}$ Restatement $t$ is an indicator variable set equal to one, if in year " $\mathrm{t}$ " a firm issues a restatement for any reason. Misconduct Restatement $_{\text {is }}$ an indicator variable set equal to one, if in year " $\mathrm{t}$ " a firm issues a restatement with alleged misconduct, as previously defined. We then control for other forces or events that may affect an executives' level of compensation. Turnover ${ }_{t}$ is an indicator variable set equal to one if there was $\mathrm{CEO}$ or CFO turnover for any reason. ${ }^{12} R O A_{t}$ is the ratio of income before extraordinary items to total assets. Sales Growth is $_{t}$ Sales $_{t}-$ Salest-1) $_{t}$ Salest-1. Adjusted Return VW $W_{t}$ is the twelve-month, value weighted, adjusted return obtained from CRSP and Return Volatility is the standard deviation of monthly returns.

The sample for these tests consists of all firms on ExecuComp from 2004 to 2019 that have necessary data. For the CEO analyses, the sample consists of 25,246 CEO-year observations, and for the CFO Analyses, we have 23,841 CFO-year observations. Moreover, all regressions include executive and firm fixed effects to control for any time-invariant characteristics of the executives

\footnotetext{
${ }^{11}$ Incentive Compensation, as opposed to Total Compensation, is examined to align with the focus of Section 304 and many clawback policies on this component of executive pay.

${ }^{12} \mathrm{We}$ employ a broader measure of turnover in these analyses because any type of turnover is likely to change executive compensation. The prior analyses were only interested in express dismissals of executives.
} 
or firms that affect compensation and industry-year fixed effects (calculated using two-digit SIC), to control for any time-varying macro-economic or industry specific trends in compensation.

Table 6 presents the results for the CEO and CFO compensation regressions. Coefficients in Column (1) suggest that CEO total incentive compensation does not appear to be affected by firms' issuance of a restatements or alleged misconduct. The results in Column (2) present a similar picture for CFO total incentive compensation. In sum, these results suggest that firms do not initiate "silent" clawbacks in response to restatements and alleged misconduct.

\subsection{3 - Tests on SEC-Enforced Clawbacks}

Up to this point, our analyses have focused on firm-initiated clawbacks. However, since the SEC has also been charged with enforcing securities laws, they may also impose clawbacks on executives when warranted. It is reasonable to suspect that if firms are not clawing back compensation, perhaps the SEC is enforcing this mechanism.

To test this possibility, we gather instances of SEC enforcement of Section 304 of SOX. We do this by searching all Litigation Releases and Accounting and Auditing Enforcement Releases for references to "Section 304." We then reviewed these instances to obtain details of the executives involved, the actions taken by the SEC, and the outcome of these enforcements, if applicable. In total, we find 43 instances of SEC-enforced clawbacks which span from 2007 to 2018. None of these instances overlap with the sample of firm-initiated clawbacks. Given the scope of the law, these clawbacks exclusively target either the CEO or CFO of a given firm. We found that 14 of these clawbacks ultimately resulted in Section-304-related reimbursements, which averaged $\$ 35$ million (this is highly skewed by one clawback of $\$ 461$ million—excluding this, the average is just over $\$ 2$ million). 
Despite the SEC initiating more clawbacks than firms, there are likely still many cases in which executives have violated Section 304 (and likely their own firm's clawback provisions) but nothing is done. Figure 3, plots the number of SEC-enforced clawbacks and the number of restatements with alleged misconduct per year from 2004 to 2018. While SEC-enforced clawbacks do not mimic the x-axis as firm-initiated clawbacks did in Figures 1 and 2, they constitute a mere fraction of cases of restatements with alleged misconduct.

\section{[INSERT FIGURE 3 HERE]}

In untabulated analyses, we replace firm-initiated clawbacks in Equation 1 with SECenforced clawbacks and re-estimate the linear probability model. ${ }^{13}$ Despite there being no overlap between firm- and SEC-enforced clawbacks, they share the same statistically significant determinants (with the sole exception of an insignificant coefficient on Clawback Policy): the SEC is more likely to initiate a clawback the longer the restatement period, in cases of overstated earnings, and at firms with multiple restatements. Together with the analyses on firm-initiated clawbacks, these results suggest that both firms and the SEC appear to be weakly reacting to the same stimuli — but neither seems overly committed to the widespread application of this governance mechanism.

\section{5 - Conclusion}

In this study, we investigate when and why firms claw back compensation from executives after a restatement. We find that in general, the presence of misconduct, more severe restatements, and previously adopted clawback policies appear to be positively associated with firms clawing back compensation. Additionally, we find that the first standalone enforcement of Section 304 of the Sarbanes-Oxley Act seems to have increased the likelihood of clawbacks, suggesting that the

\footnotetext{
${ }^{13}$ Given that the misconduct indicator would perfectly predict the occurrence of an SEC-initiated clawback (this constitutes an SEC investigation, after all), we remove this variable from the model.
} 
degree of securities law enforcement may affect firms' self-regulating behavior. Moreover, we propose $\mathrm{CEO}$ or $\mathrm{CFO}$ dismissal as a possible substitute governance mechanism to clawbacks. We find some evidence that CEO or CFO dismissal is associated with a lower likelihood of clawbacks, thus suggesting that it may be a substitute governance mechanism to clawbacks. Lastly, in supplemental analyses, we find that firms do not appear to silently claw back executives' compensation. Neither does it appear that the SEC is filling the role of enforcing clawbacks where firms are not.

This paper contributes to the literature and discussion surrounding clawbacks by researching an uninvestigated phenomenon: when a firm imposes clawbacks on its executives. Moreover, it contributes to the discussion the possible benefits of clawback policy adoption. Specifically, it provides evidence consistent with the notion that firms' adoption of these policies primarily represents window-dressing behavior. We find that clawbacks rarely occur after restatements. Among thousands of potentially deserving restatements, only fifteen are associated with compensation clawbacks. As such, while our analyses suggest possible explanations for firms' behavior surrounding clawbacks, a puzzle remains, namely: if so many firms are adopting clawback policies, and Section 304 mandates clawbacks after misconduct, why do firms not actually clawback executive compensation when they could or should? 


\section{References:}

Alsin, A. (2017). What's The Harm In Excessive CEO Pay? Answer: Long-Term Damage To Shareholders And Pension Funds. Forbes. Retrieved from https://www.forbes.com/sites/aalsin/2017/09/07/whats-the-harm-in-excessive-ceo-payanswer-long-term-damage-to-shareholders-and-pension-funds/\#22fc8fef4aea

Babenko, I., Bennett, B., Bizjak, J. M., \& Coles, J. L. (2017). Clawback Provisions. SSRN. https://doi.org/10.2139/ssrn.2023292

Brown, A. B., Davis-Friday, P. Y., \& Guler, L. (2012). Economic Determinants of the Voluntary Adoption of Clawback Provisions in Executive Compensation Contracts. SSRN Electronic Journal, (September). https://doi.org/10.2139/ssrn.1866495

Chan, L. H., Chen, K. C. W., Chen, T., \& Yu, Y. (2012). The effects of firm-initiated clawback provisions on earnings quality and auditor behavior \$. Journal of Accounting and Economics, 54(2-3), 180-196. https://doi.org/10.1016/j.jacceco.2012.05.001

Dehaan, E., Hodge, F., \& Shevlin, T. (2013). Does voluntary adoption of a clawback provision improve financial reporting quality? Contemporary Accounting Research. https://doi.org/10.1111/j.1911-3846.2012.01183.x

Denis, D. K. (2012). Mandatory clawback provisions , information disclosure, and the regulation of securities markets \$. Journal of Accounting and Economics, 54(2-3), 197200. https://doi.org/10.1016/j.jacceco.2012.07.002

Desai, H., Hogan, C. E., \& Wilkins, M. S. (2006). The reputational penalty for aggressive accounting: Earnings restatements and management turnover. Accounting Review. https://doi.org/10.2308/accr.2006.81.1.83

Francis, T., \& Fuhrmans, V. (2019). Big Companies Pay CEOs for Good Performance-and Bad - WSJ. Retrieved November 14, 2019, from https://www.wsj.com/articles/big-companiespay-ceos-for-good-performanceand-bad-11558085402

Hennes, K. M., Leone, A. J., \& Miller, B. P. (2008). The importance of distinguishing errors from irregularities in restatement research: The case of restatements and CEO/CFO turnover. Accounting Review, 83(6), 1487-1519. https://doi.org/10.2308/accr.2008.83.6.1487

Iskandar-Datta, M., \& Jia, Y. (2013). Valuation consequences of clawback provisions. Accounting Review, 88(1), 171-198. https://doi.org/10.2308/accr-50262

Karpoff, J. M., Scott Lee, D., \& Martin, G. S. (2008). The consequences to managers for financial misrepresentation. Journal of Financial Economics. https://doi.org/10.1016/j.jfineco.2007.06.003

Kedia, S., \& Rajgopal, S. (2011). Do the SEC's enforcement preferences affect corporate misconduct? Journal of Accounting and Economics, 51(3), 259-278. https://doi.org/10.1016/j.jacceco.2011.01.004

Kyung, H., Lee, H., \& Marquardt, C. (2018). The effect of voluntary clawback adoption on nonGAAP reporting. Journal of Accounting and Economics. https://doi.org/10.1016/j.jacceco.2018.09.002

Lublin, J. (2010). Law sharpens 'clawback'rules for improper pay. The Wall Street Journal, 2427. Retrieved from

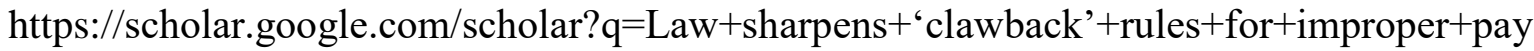
$\& \mathrm{btnG}=\& \mathrm{hl}=$ en\&as_sdt $=0 \% 2 \mathrm{C} 44 \# 0$

Mahoney, P. G. (2009). The Development of Securities Law in the United States. Journal of 
Accounting Research, 47(2), 325-347. Retrieved from http://www.jstor.org/stable/25548022

Pyzoha, J. S. (2015). Why do restatements decrease in a clawback environment? An investigation into financial reporting executives' decision-making during the restatement process. Accounting Review. https://doi.org/10.2308/accr-51049

SEC. (2009). SEC Seeks Return of \$4 Million in Bonuses and Stock Sale Profits From Former CEO of CSK Auto Corp. Retrieved from https://www.sec.gov/news/press/2009/2009167.htm

Securities and Exchange Commission (SEC). (2015). Proposed Rule in Accordance with Section 954 of the Dodd-Frank Act of 2010, 1-198. Retrieved from https://www.sec.gov/rules/proposed/2015/33-9861.pdf

Shen \& Cannella. (2002). Power Dynamics within Top Management and Their Impacts on CEO Dismissal Followed by Inside Succession Author ( s ): Wei Shen and Albert A . Cannella Jr . Source: The Academy of Management Journal, Vol . 45 , No . 6 ( Dec ., 2002 ), pp . 1195-1206 Publis. Academy of Management, 45(6), 1195-1206.

U.S. Congress. The Public Company Accounting Reform and Investor Protection Act of 2002 (The Sarbanes-Oxley Act), Pub. L. No. 116 Stat. 745 (July 30) (2002).

U.S. Congress. (2010). Dodd-Frank Wall Street Reform and Consumer Protection Act, 1-376. Retrieved from https://legcounsel.house.gov/Comps/Dodd-Frank Wall Street Reform and Consumer Protection Act.pdf

US Senate and Congress - DIVISION A - EMERGENCY ECONOMIC. Emergency Economy Stabilization Act 2008 (2008). Retrieved from https://www.congress.gov/110/plaws/publ343/PLAW-110publ343.pdf

Weiss, T. (2008). Clawbacks are in place and ineffective. Forbes. Com, 2006-2008. Retrieved from http://www.supplychaindiligence.com/docs/Forbes10-29-08.pdf 


\section{Appendix A - Variable Definitions}

\begin{tabular}{|c|c|}
\hline Variable Name & Definition \\
\hline Firm Clawed & $\begin{array}{l}\text { Equals } 1 \text { if, within two years subsequent to a given restatement, a firm } \\
\text { clawed back compensation from executives. }\end{array}$ \\
\hline \multirow[t]{2}{*}{ Clawback Policy } & $\begin{array}{l}\text { Equals } 1 \text { if firm had a clawback policy in place before the occurrence } \\
\text { of a given restatement. }\end{array}$ \\
\hline & $\begin{array}{l}\text { Equals } 1 \text { if, within six months prior or subsequent to a given } \\
\text { restatement, the firm experiences turnover as a result of dismissal, as } \\
\text { defined by Audit Analytics. Cases of death, sickness, merger and } \\
\text { acquisition activity or an interim executive were removed. }\end{array}$ \\
\hline Log Total Assets & The natural logarithm of millions of total assets from Audit Analytics \\
\hline Misconduct & $\begin{array}{l}\text { Equals } 1 \text { if a given restatement was associated with fraud or an SEC } \\
\text { investigation. }\end{array}$ \\
\hline Multiple Restatements & $\begin{array}{l}\text { Equals } 1 \text { if there were two or more restatements in the five years prior } \\
\text { to a given restatement. }\end{array}$ \\
\hline Overstatement & $\begin{array}{l}\text { And indicator variable set equal to one if a firm's restatement resulted } \\
\text { in earnings being overstated. }\end{array}$ \\
\hline Post 2009 & $\begin{array}{l}\text { Equals } 1 \text { if a given restatement date is after July 22, } 2009 \text { (the date of } \\
\text { the first standalone enforcement of SOX Section 304). }\end{array}$ \\
\hline Restatement Length & The number of months of a given restatement period. \\
\hline Executive Incentive Comp ${ }_{t}$ & $\begin{array}{l}\text { The sum of ExecuComp variables bonus, noneq_incent, } \\
\text { option_awards_fv, and stock_awards_fv }\end{array}$ \\
\hline Restatement $_{t}$ & $\begin{array}{l}\text { Equals } 1 \text { if in a given executive-year, a firm issues a restatement for } \\
\text { any reason. }\end{array}$ \\
\hline Misconduct Restatement $t_{t}$ & $\begin{array}{l}\text { Equals } 1 \text { if in a given executive-year, a firm issued a restatement with } \\
\text { alleged misconduct. }\end{array}$ \\
\hline Turnover & $\begin{array}{l}\text { Equals one if in a given executive-year, a firm experienced turnover in } \\
\text { its CEO or CFO. }\end{array}$ \\
\hline$R O A_{t}$ & $\begin{array}{l}\text { The ratio of Compustat variables income before extraordinary items } \\
\text { (ib) and total revenue (sale). }\end{array}$ \\
\hline Sales Growtht & $\left(\right.$ Salest $_{t}-$ Sales $\left._{t-1}\right) /$ Sales $_{t-1}$ \\
\hline Adj. Return $V W_{t}$ & $\begin{array}{l}\text { The twelve-month, value weighted, adjusted return obtained from } \\
\text { CRSP. }\end{array}$ \\
\hline Return Volatility & The standard deviation of monthly returns. \\
\hline
\end{tabular}


Appendix B - Clawback Details

\begin{tabular}{|c|c|c|c|c|c|c|c|}
\hline Company Name & $\begin{array}{c}\text { Clawback } \\
\text { Date }\end{array}$ & $\begin{array}{l}\text { Number of } \\
\text { Executives }\end{array}$ & $\begin{array}{c}\text { Total } \\
\text { Clawback }\end{array}$ & $\begin{array}{c}\text { Affected } \\
\text { Compensation }\end{array}$ & $\begin{array}{c}\text { Clawback } \\
\text { Percentage }\end{array}$ & Executives Affected & $\begin{array}{l}\text { Assets in } \\
\text { millions) }\end{array}$ \\
\hline $\begin{array}{l}\text { The Warnaco Group, } \\
\text { Inc. }\end{array}$ & $5 / 15 / 2007$ & 3 & $\$ 119,784$ & $\$ 6,148,793$ & $1.95 \%$ & $\begin{array}{l}\text { President/CEO, CFO, } \\
\text { and Group Pres }\end{array}$ & $\$ 1,680.97$ \\
\hline $\begin{array}{c}\text { Skilled Healthcare } \\
\text { Group, Inc. }\end{array}$ & $5 / 4 / 2010$ & 4 & $\$ 250,489$ & $\$ 4,048,476$ & $6.19 \%$ & $\begin{array}{c}\text { CEO, Pres/COO, } \\
\text { CFO, EVP/GC }\end{array}$ & $\$ 856.24$ \\
\hline $\begin{array}{l}\text { Ormat Technologies, } \\
\text { Inc. }\end{array}$ & $5 / 6 / 2010$ & 2 & $\$ 93,000$ & $\$ 1,202,026$ & $7.74 \%$ & $\mathrm{CEO}$ and $\mathrm{COO}$ & $\$ 2,043.33$ \\
\hline $\begin{array}{l}\text { Enterprise Financial } \\
\text { Services Corporation }\end{array}$ & $6 / 4 / 2012$ & 7 & $\$ 79,800$ & NA & NA & All NEOs & $\$ 3,377.78$ \\
\hline $\begin{array}{l}\text { Ignite Restaurant } \\
\text { Group, Inc. }\end{array}$ & $6 / 4 / 2013$ & 4 & $\$ 85,864$ & NA & NA & All NEOs & $\$ 201.44$ \\
\hline $\begin{array}{c}\text { General Cable } \\
\text { Corporation }\end{array}$ & $5 / 15 / 2014$ & 1 & $\$ 159,250$ & $\$ 1,523,962$ & $10.45 \%$ & $\begin{array}{c}\text { EVP/CEO of } \\
\text { division }\end{array}$ & $\$ 4,932.60$ \\
\hline $\mathrm{KBR}$, Inc & $3 / 30 / 2015$ & 7 & NA & NA & NA & $\begin{array}{c}\text { All NEOs, including } \\
\text { former CFO and } \\
\text { CAO }\end{array}$ & $\$ 4,078.00$ \\
\hline $\begin{array}{l}\text { Sonoco Products } \\
\text { Company }\end{array}$ & $4 / 20 / 2016$ & 3 & $\$ 758,889$ & $\$ 16,603,906$ & $4.57 \%$ & $\begin{array}{c}\mathrm{CEO}, \mathrm{CFO} / \mathrm{SVP} \text {, and } \\
\text { SVP }\end{array}$ & $\$ 4,013.69$ \\
\hline Akorn, Inc. & $5 / 20 / 2016$ & 3 & $\$ 1,087,000$ & $\$ 14,868,168$ & $7.31 \%$ & $\begin{array}{c}\text { CFO/EVP, EVP, and } \\
\text { EVP }\end{array}$ & $\$ 2,042.54$ \\
\hline $\begin{array}{l}\text { Iconix Brand Group, } \\
\text { Inc. }\end{array}$ & $9 / 29 / 2017$ & 2 & $\$ 2,175,000$ & $\$ 18,042,823$ & $12.05 \%$ & $\mathrm{CEO}$ and $\mathrm{CSO}$ & $\$ 2,005.51$ \\
\hline $\begin{array}{c}\text { Esterline } \\
\text { Technologies } \\
\text { Corporation } \\
\end{array}$ & $2 / 7 / 2019$ & 5 & $\$ 239,349$ & $\$ 11,979,305$ & $1.41 \%$ & All NEOs & $\$ 3,036.92$ \\
\hline \multicolumn{8}{|c|}{$\begin{array}{l}\text { This table presents the details of clawbacks in our sample. Given our criteria, multiple restatements can match to a single clawback. Total assets are } \\
\text { presented in millions. Number of executives and Total Clawback Amount correspond to the number of executives effected by a clawback and the aggregate } \\
\text { amount taken from all of them, respectively. Acronyms are as follows: CEO = Chief Executive officer, CFO = Chief Financial Officer, COO = Chief } \\
\text { Operating Officer, EVP = Executive Vice President, NEO = Named Executive Officer, CAO = Chief Accounting Officer, SVP = Senior Vice President, } \\
\text { and CSO = Chief Strategy Officer, GC = General Counsel. }\end{array}$} \\
\hline
\end{tabular}




\section{Appendix C - Clawback Excerpts}

Firm: The Warnaco Group, Inc

Date: $5 / 15 / 2007$

Filing: DEF 14A

Excerpt: "Represents discretionary bonus award granted by the Compensation Committee. Bonuses were reduced for Messrs. Gromek, Rutkowski and Tworecke by $\$ 45,600, \$ 22,440$ and $\$ 51,744$, respectively, to reflect the fiscal 2005 financial restatement, as described above under "Clawback and certain other Compensation Recovery."'

Firm: Ignite Restaurant Group, Inc.

Date: 6/4/2013

Filing: DEF 14A

Excerpt: "We do not currently have a formal policy for recovery of incentive-based compensation paid to current and former executive officers. However, despite the lack of a formal clawback policy for the recovery of incentive-based compensation awards, in connection with our recent restatement, the Compensation Committee asked each of our named executive officers (other than Ms. Ahearn who was not a named executive officer as of such time) to repay to the Company the difference between the amount each named executive officer was paid in incentive compensation and the amount each such officer would have been paid after giving effect to the restatement that occurred in fiscal year 2012. While the restatement was not the result of any management misconduct, the Compensation Committee nevertheless determined that a clawback was in the best interests of the Company and its stakeholders. The clawback applied to incentive compensation paid since fiscal year 2008, the year we implemented a measurable incentive compensation program tied to Adjusted EBITDA. As a result of the Compensation Committee's clawback decision, our named executive officers repaid an aggregate of $\$ 85,864$ to the Company, which was comprised of $\$ 40,976$ for fiscal year 2010 and $\$ 44,888$ for fiscal year 2011. The restatement did not impact fiscal year 2008 or 2009 incentive compensation."

Firm: Iconix Brand Group, Inc.

Date: $10 / 31 / 2017$

Filing: DEF 14A

Excerpt: "Per the terms of its clawback policy and in connection with the Company's recent financial restatements, in 2016 we recouped, or "clawed back," certain performance-based compensation previously paid in respect of restated periods to our former Chief Executive Officer and Chief Strategy Officer. The aggregate amount of recouped compensation was $\$ 2,175,000$ in cash and 594,877 shares of our common stock." 
Figure 1: Comparison of Clawback Polcies, Restatments and Firm-Initiated Clawbacks

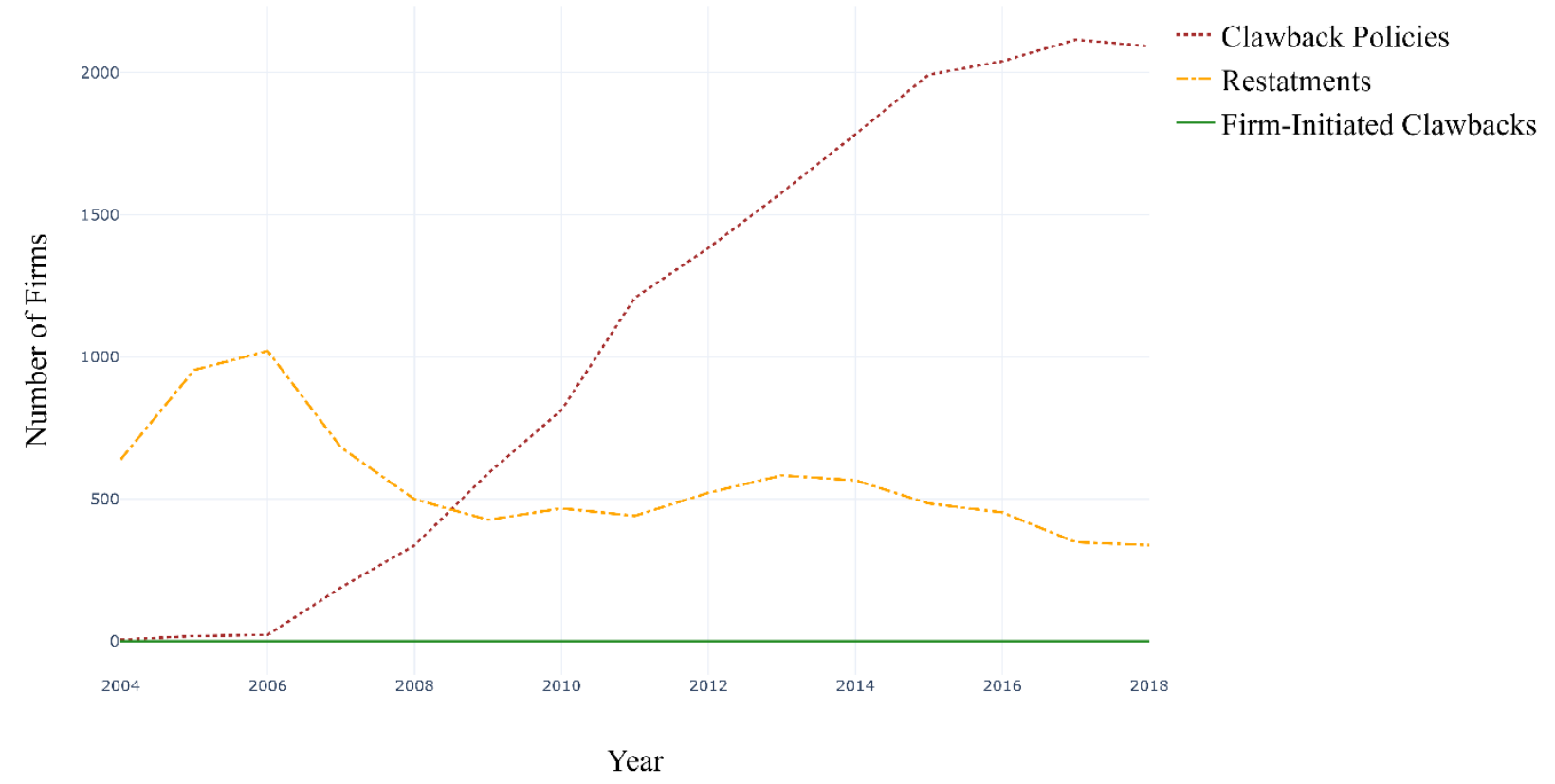

Figure 1 plots the number of firms per year that (1) had clawback policies, (2) issued a restatement, or (3) clawed back compensation. Data on firm-years was collected from Compustat and then merged with restatement and clawback data. 
Figure 2: Comparison of Restatments, Dismissals, and Firm-Initiated Clawbacks

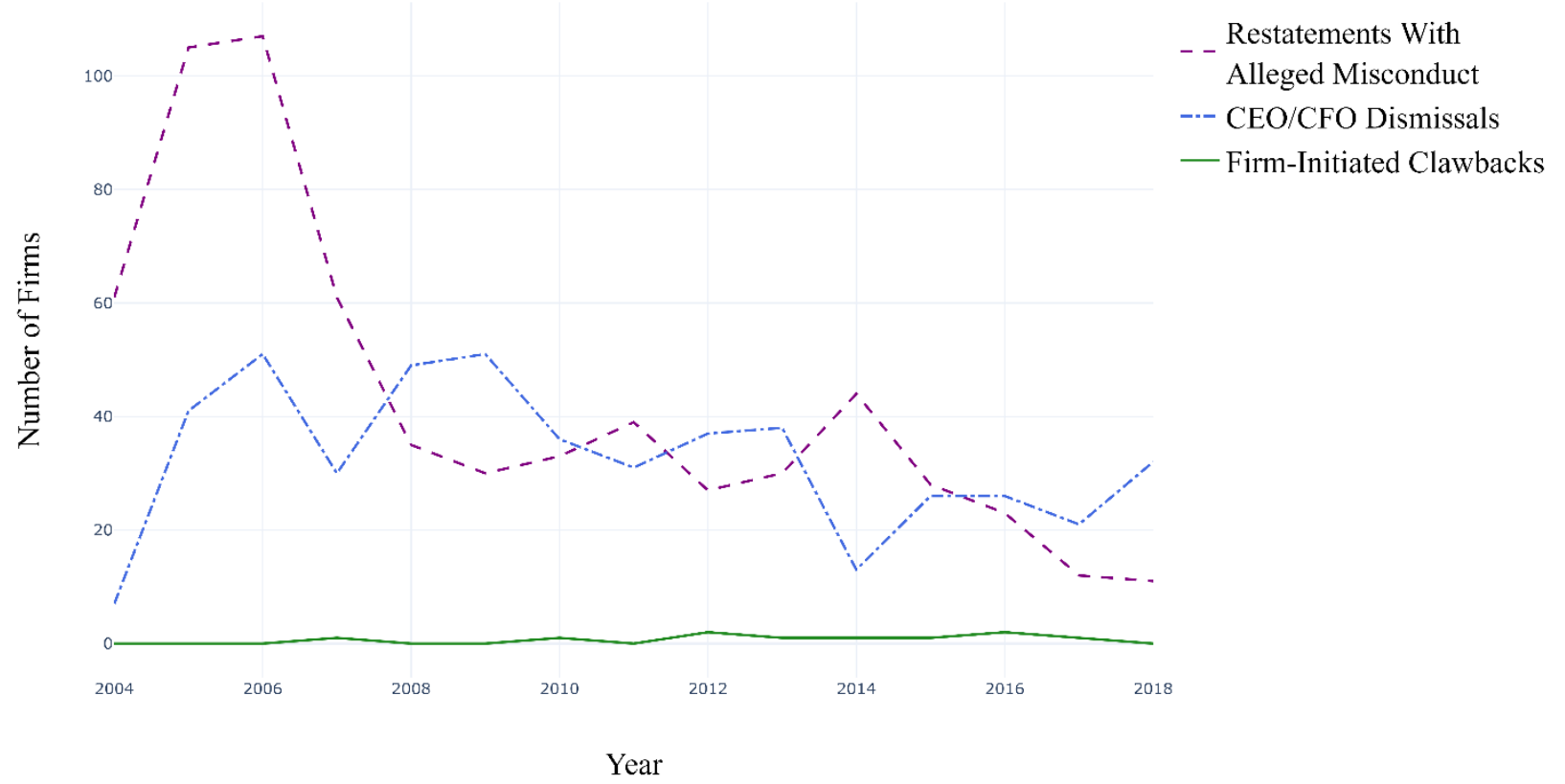

Figure 2 plots the number of firms per year that (1) issued restatements with alleged misconduct, (2) dismissed a CEO or CFO, or (3) clawed back compensation. Data on firm-years was collected from Compustat and then merged with restatement and clawback data. 
Figure 3: Comparison of Restatments and SEC-Initiated Clawbacks

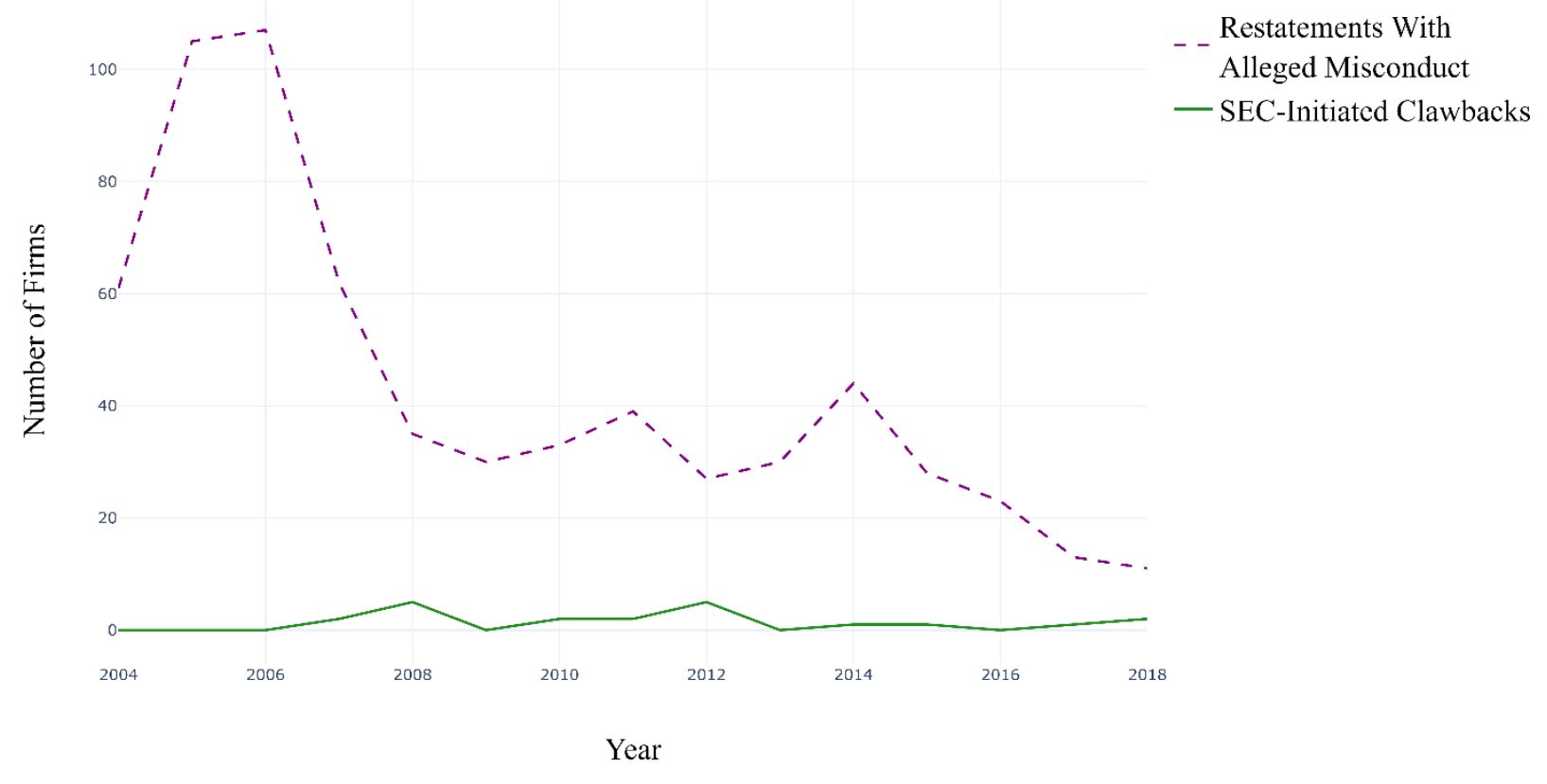

Figure 3 plots the number of firms per year that issued restatements with alleged misconduct or experienced an SEC-enforced clawback. Data on firm-years was collected from Compustat and then merged with restatement and clawback data. 
Table 1 - Sample Construction

\begin{tabular}{lc}
\hline \hline & $\begin{array}{c}\text { Number of } \\
\text { Observations }\end{array}$ \\
\cline { 2 - 2 } Total restatements from Audit Analytics & 18,161 \\
Less: restatements outside years 2004-2019 & $(3,131)$ \\
Less: restatements with zero sales & $(871)$ \\
Less: restatements with zero total assets & $(3,242)$ \\
Less: restatements with missing data & $(4,181)$ \\
Observations in Sample & 6,736 \\
\end{tabular}


Table 2 - Descriptive Statistics

\begin{tabular}{|c|c|c|c|c|c|c|}
\hline \multicolumn{7}{|l|}{ Panel A: Full Sample } \\
\hline Variable & $\mathrm{N}$ & Mean & S.D. & 0.25 & 0.5 & 0.75 \\
\hline Firm Clawed & 6736 & 0.002 & 0.047 & 0 & 0 & 0 \\
\hline Misconduct & 6736 & 0.074 & 0.262 & 0 & 0 & 0 \\
\hline Clawback Policy & 6736 & 0.213 & 0.409 & 0 & 0 & 0 \\
\hline Restatement Length & 6736 & 23.356 & 19.443 & 8.969 & 17.939 & 32.953 \\
\hline Overstatement & 6736 & 0.431 & 0.495 & 0 & 0 & 1 \\
\hline Multiple Restatements & 6736 & 0.412 & 0.492 & 0 & 0 & 1 \\
\hline Dismissal & 6736 & 0.009 & 0.096 & 0 & 0 & 0 \\
\hline Post 2009 & 6736 & 0.517 & 0.500 & 0 & 1 & 1 \\
\hline Log Total Assets & 6736 & 6.371 & 2.313 & 4.8689 & 6.4524 & 7.8974 \\
\hline \multicolumn{7}{|c|}{$\begin{array}{l}\text { Panel B: Firm Clawed Partition } \\
\end{array}$} \\
\hline & \multicolumn{2}{|c|}{ Clawed = 1} & \multicolumn{2}{|c|}{ Clawed $=0$} & & \\
\hline Variable & $\mathrm{N}$ & Mean & $\mathrm{N}$ & Mean & \multicolumn{2}{|c|}{ Difference } \\
\hline Firm Clawed & 15 & 1.000 & 6721 & 0.000 & \multicolumn{2}{|c|}{$1.000 * * *$} \\
\hline Misconduct & 15 & 0.400 & 6721 & 0.074 & \multicolumn{2}{|c|}{$0.326 * *$} \\
\hline Clawback Policy & 15 & 0.667 & 6721 & 0.212 & \multicolumn{2}{|c|}{$0.455 * * *$} \\
\hline Restatement Length & 15 & 31.530 & 6721 & 23.337 & \multicolumn{2}{|c|}{8.192} \\
\hline Overstatement & 15 & 0.867 & 6721 & 0.430 & \multicolumn{2}{|c|}{$0.437 * * *$} \\
\hline Multiple Restatements & 15 & 0.667 & 6721 & 0.412 & \multicolumn{2}{|c|}{$0.255 *$} \\
\hline Dismissal & 15 & 0.000 & 6721 & 0.009 & \multicolumn{2}{|c|}{$-0.009 * * *$} \\
\hline Post 2009 & 15 & 0.867 & 6721 & 0.516 & \multicolumn{2}{|c|}{$0.351 * * *$} \\
\hline Log Total Assets & 15 & 7.690 & 6721 & 6.368 & \multicolumn{2}{|c|}{$1.323 * * *$} \\
\hline
\end{tabular}

This table presents descriptive statistics for the restatement sample and Firm Clawed partitions. All continuous variables are winsorized at the first and ninety-ninth percentiles. P-values are based on two-tailed t-tests of the difference in means. ${ }^{*}, *, * * *$ indicate statistical significance at the $0.10,0.05$, and 0.01 levels, respectively. 
Table 3 - Sample Correlations

\begin{tabular}{lccrrrrrrr}
\hline \hline Variable & $(1)$ & \multicolumn{1}{c}{$(2)$} & \multicolumn{1}{c}{$(3)$} & \multicolumn{1}{c}{$(4)$} & \multicolumn{1}{c}{$(5)$} & \multicolumn{1}{c}{$(6)$} & \multicolumn{1}{c}{$(7)$} & \multicolumn{1}{c}{$(8)$} & \multicolumn{1}{c}{$(9)$} \\
\hline Firm Clawed & & 0.059 & 0.052 & 0.016 & 0.042 & 0.024 & -0.009 & 0.033 & 0.034 \\
Misconduct & 0.059 & & -0.046 & 0.134 & 0.123 & -0.010 & 0.010 & -0.075 & -0.028 \\
Clawback Policy & 0.052 & -0.046 & & -0.019 & -0.144 & 0.088 & -0.019 & 0.458 & 0.330 \\
Restatement Length & 0.020 & 0.136 & -0.030 & & 0.192 & -0.017 & -0.008 & -0.083 & 0.145 \\
Overstatement & 0.042 & 0.123 & -0.144 & 0.234 & & -0.012 & 0.040 & -0.182 & -0.111 \\
Multiple Restatements & 0.024 & -0.010 & 0.088 & -0.017 & -0.012 & & 0.028 & 0.052 & 0.026 \\
Dismissal & -0.009 & 0.010 & -0.019 & 0.000 & 0.040 & 0.028 & & -0.031 & -0.040 \\
Post 2009 & 0.033 & -0.075 & 0.458 & -0.121 & -0.182 & 0.052 & -0.031 & & 0.196 \\
Log Total Assets & 0.027 & -0.027 & 0.315 & 0.152 & -0.106 & 0.028 & -0.037 & 0.187 & \\
\hline
\end{tabular}

This table presents correlation coefficients for the restatement sample. All continuous variables are winsorized at the first and ninety-ninth percentiles. Pearson Correlations appear below the diagonal and Spearman Correlations appear above the diagonal. 
Table 4 - Determinants of Compensation Clawbacks

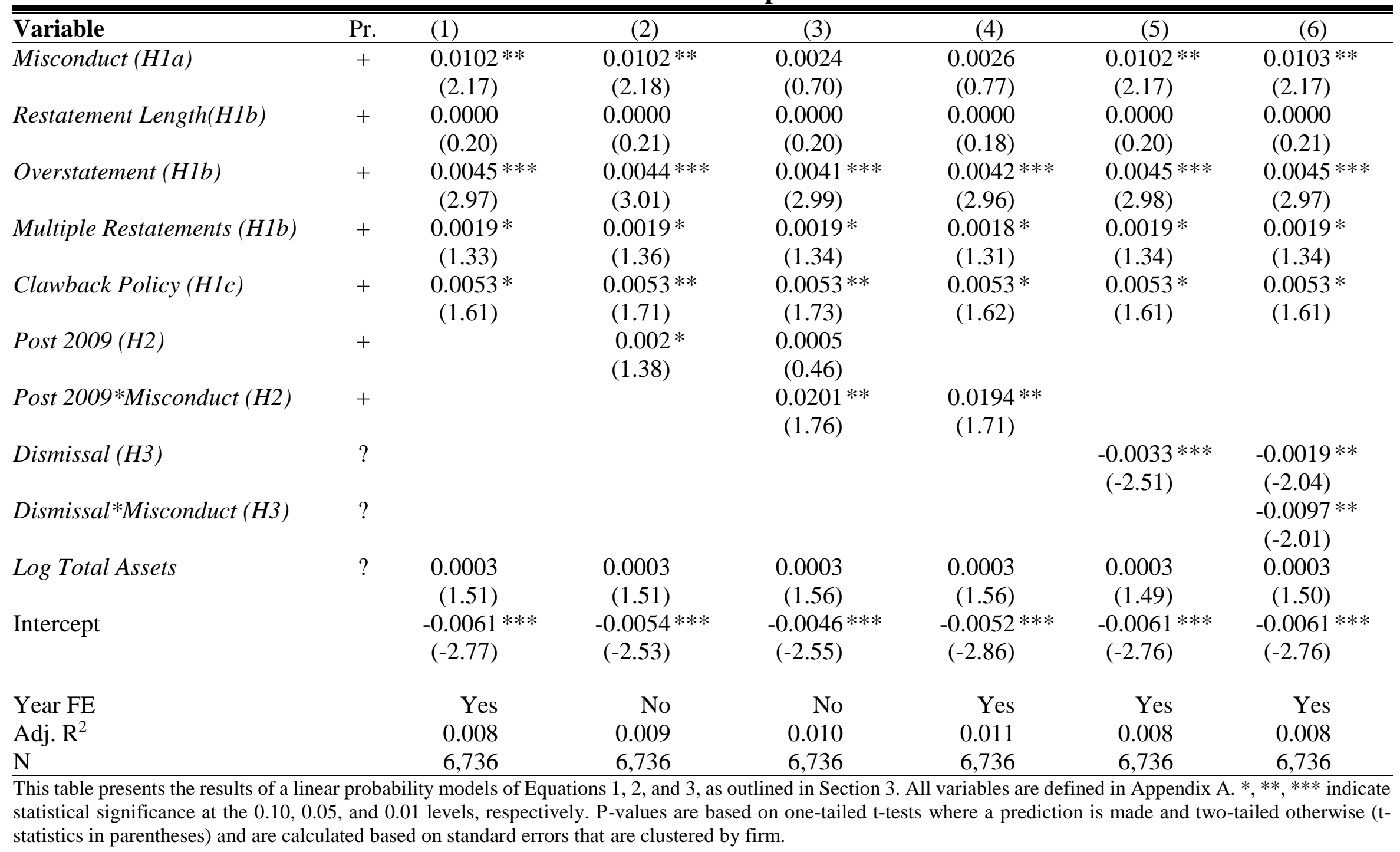


Table 5 - Analyses on Misconduct Sub-Sample

\begin{tabular}{llllccc}
\hline \hline Panel A - Descriptive Statistics & & \multicolumn{5}{c}{} \\
\hline \hline Variable & N & Mean & S.D. & 0.25 & 0.50 & 0.75 \\
\hline Firm Clawed & 500 & 0.012 & 0.109 & 0 & 0 & 0 \\
Clawback Policy & 500 & 0.146 & 0.353 & 0 & 0 & 0 \\
Restatement Length & 500 & 32.673 & 22.691 & 14.949 & 26.941 & 44.945 \\
Overstatement & 500 & 0.646 & 0.479 & 0 & 1 & 1 \\
Multiple Restatements & 500 & 0.394 & 0.489 & 0 & 0 & 1 \\
Dismissal & 500 & 0.018 & 0.133 & 0 & 0 & 0 \\
Post 2009 & 500 & 0.384 & 0.487 & 0 & 0 & 1 \\
Log Total Assets & 500 & 6.151 & 2.482 & 4.419 & 6.243 & 7.856 \\
\hline \hline
\end{tabular}

\section{Panel B - Regressions}

\begin{tabular}{|c|c|c|c|c|}
\hline \multirow[b]{2}{*}{ Variable } & \multicolumn{4}{|c|}{ Dependent Variable $=$ Firm Clawed } \\
\hline & Pr. & $(1)$ & $(2)$ & $(3)$ \\
\hline \multirow[t]{2}{*}{ Restatement Length (HIb) } & + & -0.0001 & -0.0001 & -0.0001 \\
\hline & & $(-0.401)$ & $(-0.416)$ & $(-0.394)$ \\
\hline \multirow[t]{2}{*}{ Overstatement (H1b) } & + & $0.0162 * *$ & $0.0162 * *$ & $0.0162 * *$ \\
\hline & & $(2.253)$ & $(2.319)$ & $(2.251)$ \\
\hline \multirow[t]{2}{*}{ Multiple Restatements (HIb) } & + & $0.0288 * * *$ & $0.0274 * * *$ & $0.029 * * *$ \\
\hline & & $(2.452)$ & $(2.461)$ & $(2.453)$ \\
\hline \multirow[t]{2}{*}{ Clawback Policy (HIc) } & + & 0.017 & 0.0173 & 0.0169 \\
\hline & & $(0.69)$ & $(0.721)$ & $(0.672)$ \\
\hline \multirow[t]{2}{*}{ Post 2009 (H2) } & + & & 0.0132 & \\
\hline & & & $(1.231)$ & \\
\hline \multirow[t]{2}{*}{ Dismissal (H3) } & & & & -0.0142 \\
\hline & & & & $(-1.1)$ \\
\hline \multirow[t]{2}{*}{ Log Total Assets } & & 0.0022 & 0.0022 & 0.0022 \\
\hline & & $(1.362)$ & $(1.531)$ & $(1.36)$ \\
\hline \multirow[t]{2}{*}{ Intercept } & & $-0.0341 * * *$ & $-0.027 * *$ & $-0.0342 * *$ \\
\hline & & $(-2.232)$ & $(-2.353)$ & $(-2.231)$ \\
\hline Year FE & & Yes & No & Yes \\
\hline Cluster SE by Firm & & Yes & Yes & Yes \\
\hline Adj. $R^{2}$ & & 0.034 & 0.027 & 0.033 \\
\hline $\mathrm{N}$ & & 500 & 500 & 500 \\
\hline
\end{tabular}

This table presents descriptive statistics the results of linear probability models of Equations 1-3, as outlined in Section 3, but only in cases of restatements with alleged misconduct (Misconduct $=1)$. All variables are defined in Appendix A. *, **, *** indicate statistical significance at the 0.10, 0.05, and 0.01 levels, respectively. P-values are based on one-tailed t-tests where a prediction is made and two-tailed otherwise (t-statistics in parentheses) and are calculated based on standard errors that are clustered by firm. Year Fixed effects were excluded in Column 2 due to high multicollinearity with Post 2009. 
Table 6 - Tests of "Silent" Clawbacks

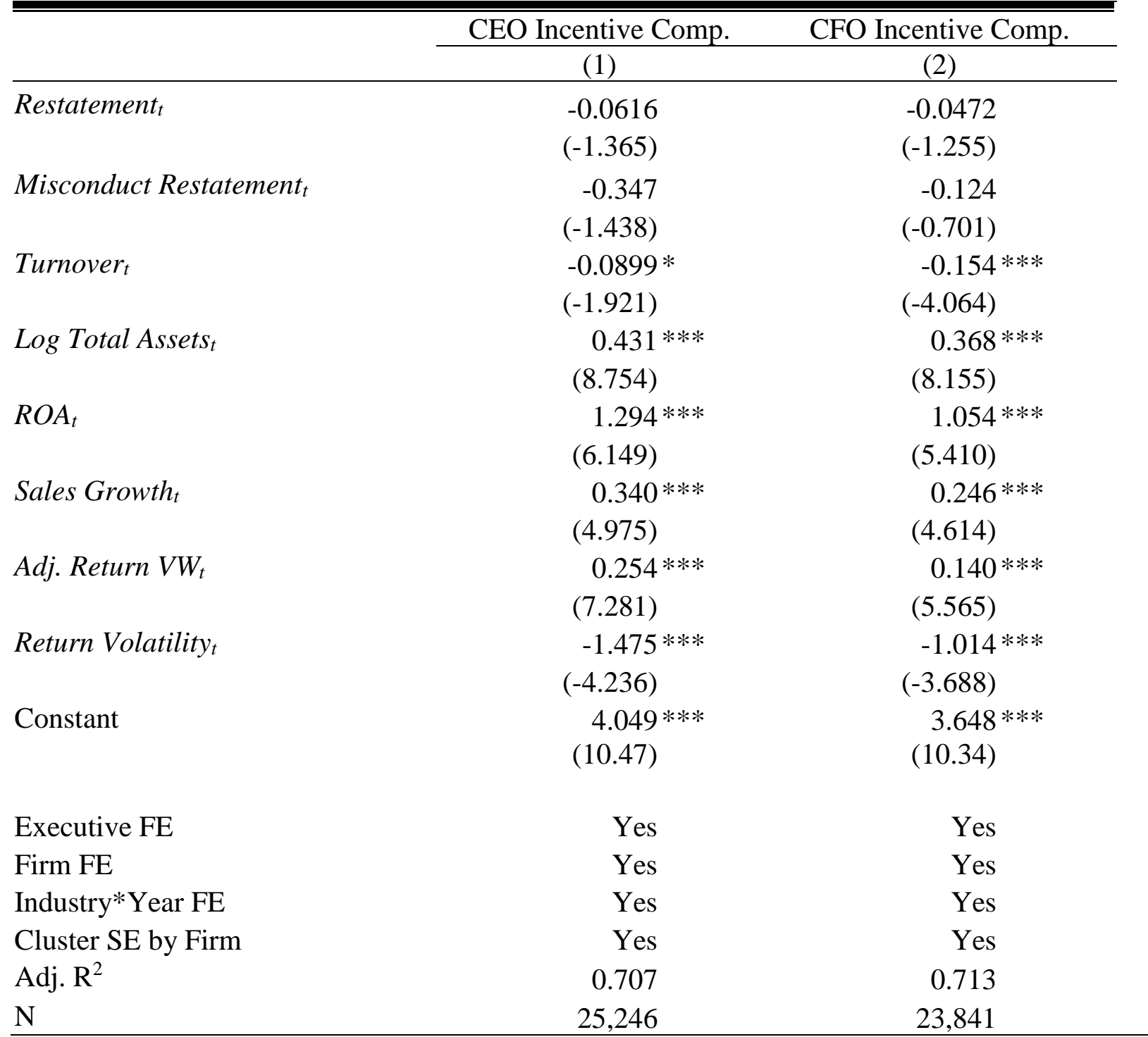

This table presents the results of Equation 4 (as outlined in Section 4.5.2), modeled using ordinary least squares. All variables are defined in Appendix A. *, **, *** indicate statistical significance at the 0.10, 0.05, and 0.01 levels, respectively. P-values are based on two-tailed t-tests (t-statistics in parentheses) and are calculated based on standard errors that are clustered by firm. 